\title{
Constraints to USAID MARKET II Soybean Production Project in Benue State Nigeria
}

https://dx.doi.org/10.4314/jae.v22i3.14

Iwuchukwu, Juliana. C.

Department of Agricultural Extension,

University of Nigeria, Nsukka Enugu State, Nigeria.

E-mail : juliana.iwuchukwu@unn.edu.ng

Phone: +2348063276459

${ }^{*}$ Corresponding author:

\section{Beeior,Chris.T.}

Department of Agricultural Education,

College of Education Oju, Benue State, Nigeria.

Email:beeior4real@yahoo.com

Phone: 07030316601

\section{Abstract}

The study examined the constraints hindering the success of USAID MARKETS II soybean production project in Benue State, Nigeria. The population for the study included all 509 project participant soybean farmers of USAID MARKETS II project. A total sample of 150 respondents were purposively selected from all the eight soybean producing local government areas in the State who were the participants of the project. Interview schedule was used for data collection, while percentage, mean score and factor analysis were used to analyze the data. The results of the study revealed that project participants had positive and negative perceptions towards USAIDMARKETS II soybean production project in Benue State. Economic, institutional and linkage constraints were extracted as constraints hindering the success of the project. Active participation of government in providing logistic support and frequent monitoring and evaluation of the project will help to overcome lapses, boost interest and capabilities of farmers/ participants in the project and ensure success of the project.

\section{Key Words: Constraints, USAID MARKETS II, soybean}

\section{Introduction}

Soyabean (Glycine max) a leguminous plant belongs to the family of Fabaceae (Heuze \& Tran, 2015). Soyabean originated in South Eastern Asia (including China, Japan, and Korea) and was domesticated more than 3,000 years ago for its edible seeds and young pods (Ecocrop,2012). The earliest known cultivation of soybean in Africa was in Egypt in 1858 (Shurtleff and Akiko, (2009) in Soybeans Africa, 2016). Ezedinma (1964), in Adelodun, (2011) reported that soybean was first introduced to Nigeria in 1908 by the British. The crop is successfully grown in many 
Creative commons User License: CC BY-NC-ND

Abstracted by: EBSCOhost, Electronic Journals Service (EJS), Google Scholar, Journal Seek, Scientific Commons,

Food and Agricultural Organization (FAO), CABI and Scopus
Journal of Agricultural Extension

Vol. 22 (3) October, 2018

ISSN(e): 24086851; ISSN(Print); 1119944X

http://journal.aesonnigeria.org

http://www.aiol.info/index.phpliae

Email: editorinchief@aesonnigeria.org

states in Nigeria using low agricultural input. At present, the major soybean producing states in the country are Benue, Kaduna, Taraba, Plateau and Niger.

Soybean is one of the most nutritious crop in the world. It contains at least $100 \%$ more proteins than any other common crop and yields 5-10 times more protein per unit area than other crops (Soybean Africa 2016). The protein in soybean is also balanced. It contains all the essential amino acids, which the body cannot manufacture.

Various strategies have been implemented to accelerate the production of soybean in Nigeria (Biam and Aja, 2012). One of such projects is the USAID MARKETS II, Soybean production project which was introduced in 2012 in Benue State, Nigeria by the United State Agency for International Development (USAID). MARKETS II is packaged with modern soybean production technologies aimed at teaching the relevant agronomic practices and empowering Benue State farmers to boost production of soybean. The project is actually a system of innovation where USAID is responsible for the entire sponsorship of the project via Chemonics International, while Benue State Agricultural Development Programme (BNARDA) and Hule Nigeria Limited (Hule Nig LTD) provide extension services and add value to the commodity by processing it into different soy products. This project concentrates on smallholder farmers, who are in groups of 20 - 35 persons trained on various agronomic technologies by the project (USAID, 2015). Some of these technologies include improved soybean varieties; line planting technology; rhizobium inoculation; use of poultry manure; crop rotation; improved marketing systems; seed treatment; pest and disease control; weed management using herbicides and record keeping (USAID MARKETS II Package of Practices (POP), 2013).

Despite five complete years of the introduction of USAID MARKETS II soybean production project in Benue State, there are indications that all is not well with project. The perception of the beneficiaries and possible factors constraining success are not clear.

\section{Methodology}

The study was carried out in Benue State, Nigeria. The population for the study comprised all registered MARKETS II soybean farmers in the entire eight soybean producing local government areas (LGAs) in Benue State. These LGAs were Tarkaa, Gboko, Gwer and Buruku from Benue North West Senatorial District (Zone B) and Konshisha, Ushongu, Kwande, and Vandeikya LGAs from Benue North East Senatorial District (Zone A).

Multistage, purposive and proportionate random sampling techniques were employed in selecting the respondents for the study. In the first stage, all the eight LGAs participating in the project were used for the study. In stage two, two soybean farmers associations (S.F.A.) that participated in the project were randomly selected from each LGA giving a total of sixteen (16) soybean farmers associations. In stage three, proportionate sampling was used in selecting the respondents from each soybean farmers' association (30\% of the members of each soybean farmers association was selected) to obtain a total of 150 respondents that were used for the study. Interview 
Creative commons User License: CC BY-NC-ND

Abstracted by: EBSCOhost, Electronic Journals Service (EJS), Google Scholar, Journal Seek, Scientific Commons,

Food and Agricultural Organization (FAO), CABI and Scopus
Journal of Agricultural Extension

Vol. 22 (3) October, 2018

ISSN(e): 24086851; ISSN(Print); 1119944X

http://journal.aesonnigeria.org

http://www.ajol.info/index.php/iae

Email: editorinchief@aesonnigeria.org

schedule which dealt on specific objectives of the study was used to collect primary data for the study.

To obtain information on farmer's perception of USAID MARKETS II soybean production project, a five points Likert-type scale of strongly agree $=4$, agree $=3$, undecided $=2$ disagree $=1$ and strongly disagree $=0$ with a mean of 2.0 was used. In order to obtain a cut-off point, 0.05 was added to the mean to get 2.05 and was used as the upper limit while 0.05 was deducted from 2.0 to get 1.95 , which was used as the lower limit. Both negative and positive statements were presented to the farmers in order to ensure precision and accuracy in their responses. Any positive response option with mean score greater than or equal to 2.05 was regarded as positive perception towards USAID MARKETS II Project while any positive statement with mean score equal to or less than 1.95 was regarded as negative perception towards USAID MARKETS II Project. On the other hand, negative statements or variables with mean scores greater than or equal to 2.05 were regarded as negative perceptions whereas those with mean scores of 1.95 and below were regarded as positive perceptions towards the project.

The rotated factor matrix was used to isolate the constraint factors to the soybean production project in Benue State. Only variables with loadings of 0.40 and above were considered in naming the factors.

\section{Results and Discussion}

\section{Farmer's Perception of USAID MARKET II Soybean Production Project}

Table 1 shows that the respondents had positive perceptions on the following attributes of the project; crop rotation adopted is good and easy to practice $\left(x^{-}=3.88\right.$; SD = 0.59), USAID MARKETS II soybean production technologies have relative advantage over previous practices $\left(x^{-}=3.78\right.$; $\left.S D=0.57\right)$, technologies are generally efficient $(\bar{x}=3.78 ; \mathrm{SD}=0.57)$ among others.

The respondents were in agreement that crop rotation adopted in the project is good and easy to practice. Most of the farmers perceived the farming practice as being good and easy to practice since it is not different from what they are used to. In addition, cheap availability of farm land to project participants also favoured the adoption of the cropping system in the study area.

Participants of the project had positive perception that USAID MARKETS II soybean production technologies were efficient and had relative advantage over their previous practices. This may be attributed to the fact that the farmers were involved in the activities of the project over the years and are knowledgeable about it and could also express their feelings about the project in respect to its benefits and advantages. According to Aphunu and Nwabueze (2012) the higher the knowledge of a given project to farmer, the more they perceive its impact on their lives.

Participating farmers perceived the new technologies as being helpful. Most of the farmers attested that the inception of USAID MARKETS II project did not only expose them to other uses of soybean such as soya oil, powdered soya milk, and soy cake 
Creative commons User License: CC BY-NC-ND

Abstracted by: EBSCOhost, Electronic Journals Service (EJS), Google Scholar, Journal Seek, Scientific Commons,

Food and Agricultural Organization (FAO), CABI and Scopus
Journal of Agricultural Extension

Vol. 22 (3) October, 2018

ISSN(e): 24086851; ISSN(Print); 1119944X

http://journal.aesonnigeria.org

http://www.aiol.info/index.phpliae

Email: editorinchief@aesonnigeria.org

but also boost their income to purchase other family needs. The result is in consistent with that of Daudu and Madukwe (2013) that soybean farmers in Benue State process soybean into different uses such as soya milk and cake.

Soybean farmers participating in the project also agreed that the new soybean production technologies resulted to more farm output. This indicates that they had experience an increase in farm output in recent times than previous year's harvest as a result of the introduction of new technologies to them.

The project participants also agreed that improved soybean seeds were good and readily available to the farmers participating in the project. This motivated most of the farmers to give the new seeds a trial. Farmers are usually discouraged when a new technology they desire becomes a scarce commodity. The findings corroborate the finding of Mignouna et al. (2011) that farmers who perceive new technology as being consistent with their needs and compatible to their environment are likely to adopt since they find it as positive investment.

However, project participants had negative perceptions on some attributes of USAID MARKETS II project. These negative perceptions were evident in bureaucracy in accessing help/ support from the project $\left(x^{-}=3.57 ; \mathrm{SD}=0.73\right)$ and the cost ineffectiveness of some of the technologies $(x=3.49$; $S D=1.15)$ among others as seen in Table 1. The negative perception could hinder the overall success of the project if not improved upon.

Bureaucracy in accessing help from USAID MARKETS II would hinder the success of the project. For example, most project farmers lamented that after four years of application for a tractor the request is still receiving attention.

The cost ineffectiveness of some USAID MARKETS II soybean production technologies were regarded as negative attributes of the project. Technology like line planting which requires the use of tractors to construct technical ridges was not affordable by the farmers, hence they perceived it as not being cost effective. This implies that the likelihood of adopting the technology would be low. Another technology identified by respondents as not being cost effective was application of fertilizer in a plot of land before ploughing and planting of soybean. This may be because most farmers could not procure the commodity due to its untimely availability and scarcity. Timely provision of quality fertilizers to the farmers through their cooperatives at affordable rate will enhance the adoption of the technology and also increase famers" yield. This view has been expressed by Okoli, Agbasi, and. Anigbogu, (2015) that fertilizers obtained by cooperative farmers in Anambra State significantly influenced their yield.

Participating farmers also agreed that the project did not assist them to access better farm inputs like fertilizers, agrochemicals, spraying machines, tractors etc. Most of the farmers agreed that they purchased their farm inputs from open markets against the initial plan of linking farmers with appropriate input dealers.

Nevertheless, Table1 also shows that negative statements with means scores below the cut off mark implies positive perception towards the project. For instance, "USAID MARKETS II does not assist farmers to access credit facilities" (1.94) and "soybean seeds are not the variety that consumers want" (0.99) means that USAID MARKETS 
Creative commons User License: CC BY-NC-ND

Abstracted by: EBSCOhost, Electronic Journals Service (EJS), Google Scholar, Journal Seek, Scientific Commons,

Food and Agricultural Organization (FAO), CABI and Scopus
Journal of Agricultural Extension

Vol. 22 (3) October, 2018

ISSN(e): 24086851; ISSN(Print); 1119944X

http://journal.aesonnigeria.org

http://www.ajol.info/index.php/iae

Email: editorinchief@aesonnigeria.org

II assists farmers to get credit and that consumers like the soybean seed varieties introduced by the project.

Table 1 also reveals that mean scores on famers" perception towards USAID MARKETS II had high standard deviation values. The high standard deviation indicates wide disparity in the respondent's perception of the project. This implies that respondents were not unanimous in their perception of the project which may be attributed to differences in their personal, social and economic attributes among other factors.

Table 1: Farmers perception of USAID MARKETS II soybean production project Characteristics of technologies / variables Mean SD $\left(x^{-}\right)$

\section{Positive statements}

Crop rotation adopted is good and easy to practice.

USAID MARKETS II soybean production technologies have relative advantage over

Technologies are generally efficient

Technologies help the farmers to improve nutritional use of grown and purchase of basic

food

Technologies result to more farm output

It is easy to manage the farm when soybean is grown

$3.75^{\star} \quad 0.74$

Technologies offer observable result

Improve soybean seeds are readily available

$3.73^{*}$

$3.69^{*}$

$3.68^{*}$

$3.63^{*}$

0.59

Technologies are gender friendly

0.96

Rhizobium inoculation is not stressful

USAID MARKETS II offer more access to extension services

$3.53^{*}$

Seed treatment is easy and gives positive result.

Technologies result to better water management

$3.43^{*} \quad 0.85$

$3.37^{*} 0.73$

The seeds are resistant to pests and insects

The technologies are compatible with our farming practices

Record keeping is not tedious

Soybean produced are purchased by the contracted processor

management is easy and gives positive result

Technologies gives pumper harvest to the farmer

\section{Negative statements}

There is bureaucracy in accessing help/ support from the project

Some of the technologies are not cost effective

The project does not assist farmers to access better farm inputs

Some of the soybean production technologies are not easy to use by the farmers

USAID MARKETS II does not assist farmers to access credit facilities

Output and productivity of soybean farmers have not improved because of the project.

The seeds are not the variety that the consumer wants

Technologies cannot be tested before adoption

The seeds cannot be stored for a long time

The project does not target the beneficiaries and was not directed to the real producers

${ }^{*}$ Positive response options with mean $\geq 2.05$ (Positive Perception towards USAID MARKETS II)

*Negative response options with mean $\geq 2.05$ (Negative perception towards USAID MARKETS 


\section{Factors Constraining the Success of USAID MARKETS II Soybean Production Project}

Table 2 shows that three constraint factors were extracted based on the responses of the soybean farmers who participated in the project. Factors 1, 2 and 3 were named economic, institutional and linkage constraints respectively.

\section{Economic constraint (Factor 1)}

The loadings show that untimely supply of inputs (0.57) loaded high under economic constraints. Untimely supply and scarcity of inputs restrict farmers from procuring farm inputs necessary for adoption of improved varieties on time. This is because most of the soybean varieties used in the projects have specific dates for carrying out farming activities like ploughing, planting, weeding and application of fertilizers if farmers are to maximize output. Also, the high cost and scarcity of inputs discourages farmers by making them to grow alternative crops like cassava and sweet potatoes that can give high yield without application of scarce inputs like fertilizers. Damola (2010), reported that difficulty in procuring agricultural inputs at the right time had discouraged the use of agricultural inputs and technologies among farmers.

Inadequate funds on part of farmers (0.56) was another constraint that loaded high under economic factors as constraining the success of the project. It has limited many participating farmers in the project from boosting their farm production because they operate small scale farms that gives very low monthly income resulting to low or no saving for future investment. Besides, most of the farmers had no access to credit facilities to fund their farming operations. This made them to perpetually operate small scale soybean farming. Oriole (2004) stressed that unless credit facilities are provided to small scale farmers, otherwise majority of them are seriously handicapped in adopting new and profitable farm technologies.

Lack of technical knowhow (0.49) also loaded high under economic constraints, most farmers participating in the project lack the requisite skills to successfully adopt the technologies introduced by the project. This result corroborates with Ajayi (2002) who reported that most farmers lack the expected knowledge to operate modern technology and as such may not adopt such technologies.

Poor market information (0.46) factored as an economic constraint hindering the success of USAID MARKETS II project. It was observed from personal interaction with the respondents that project farmers were still victims of price taking as against the initial aim of USAID MARKETS II project because most of the farmers were not aware of the ready market arranged for their produce with Hule Nigeria limited. The soybean market was highly dominated by middle men who buy soybeans from project participants at take away prices using different kinds of measurement and supplied to Hule Nig. Limited to make high gain at the expense of the poor rural farmers. Hence poor marketing system remain a major problem affecting soybean farmers in Benue State. However, the findings disagreed with Mustapha et al. (2012) who reported that marketing of soybean produce was not a constraint in Taraba State.

\section{Institutional constraints (Factor 2)}

These are constraints that result from failure of government or her institutions to play their roles towards the success of USAID MARKETS II project. Prominent among 
Creative commons User License: CC BY-NC-ND

Abstracted by: EBSCOhost, Electronic Journals Service (EJS), Google Scholar, Journal Seek, Scientific Commons,

Food and Agricultural Organization (FAO), CABI and Scopus
Journal of Agricultural Extension

Vol. 22 (3) October, 2018

ISSN(e): 24086851; ISSN(Print); 1119944X

http://journal.aesonnigeria.org

http://www.aiol.info/index.phpliae

Email: editorinchief@aesonnigeria.org

them was poor government support (0.75). Benue State Government and local government's authorities of those communities hosting the project failed to create enabling environment that would enhance the success of the project. There was also improper monitoring and evaluation of USAID MARKETS II project by the officials of the project (0.68). Stakeholders of the project were supposed to be monitored and evaluated at each stage of the project to ensure that all the people concerned play their respective roles and adhere strictly to project design in order to achieve success. Akinnagbe and Olaolu (2016) lamented that most programme implementers in Nigeria do not fully appreciate the primary purpose of programme monitoring and evaluation. They added that monitoring and evaluation are supposed to be built-in as an integral part of every agricultural extension programme.

Another factor that loaded under institutional constraints was top down approach in project design, planning and implementation (0.51). Like many other agricultural projects and programmes in Nigeria, participants of USAID MARKETS II were not involved in the designing and planning of the project thereby denying them opportunity of giving good suggestions for the success of the project. As a result, the project may lack the necessary grass-root support and the regular mobilisation required for its success. Akinnagbe and Olaolu (2016) affirmed that any agricultural programme that does not involve the local people is bound to fail.

Herdsmen attacks on farmers was also an institutional problem constraining the success of USAID MARKETS II (0.42). Farmers in the study area have abandoned their farms for cattle herdsmen to avoid conflict and consequently death. There have been reports of farmers-herdsmen clashes resulting in loss of lives, crops and other properties. (Dimelu, Salifu and Igbokwe, 2016)

\section{Linkage constraints (Factor 3 )}

Inadequate extension contact (0.60) loaded as linkage constraints inhibiting the success of USAID MARKETSII soybean production project. Some project participants of USAIDMARKETS II alleged they never had contact with any extension agent since the inception of the project. This suggests that they did not have relevant information to stimulate adoption of new technologies. There are reports of the ineffectiveness of extension services due to insufficient number of extension workers (Agada, 2015, Tiwari, 2010).

Non-interaction between and among stake holders (0.51) was also factored as a linkage constraint. Like many other agricultural programmes and project in Nigeria, farmers and other stakeholders were not carried along in the designing, planning and implementation of USAID MARKETS II project. This may reduce the support and success that the project would have recorded. 
Creative commons User License: CC BY-NC-ND

Abstracted by: EBSCOhost, Electronic Journals Service (EJS),

Google Scholar, Journal Seek, Scientific Commons,

Food and Agricultural Organization (FAO), CABI and Scopus
Journal of Agricultural Extension

Vol. 22 (3) October, 2018

ISSN(e): 24086851; ISSN(Print); 1119944X

http://journal.aesonnigeria.org

http://www.ajol.info/index.php/jae

Table 2: Constraints to the success of USAID MARKET II project

\begin{tabular}{|c|c|c|c|}
\hline \multirow[b]{2}{*}{ Variables } & \multicolumn{3}{|c|}{ Factors } \\
\hline & 1 & 2 & 3 \\
\hline Poor market information & 0.457 & 0.444 & 0.029 \\
\hline $\begin{array}{l}\text { Poor government support for USAID MARKETS II project } \\
\text { Bureaucratic bottlenecks } \\
\text { High cost of some technologies introduced by the project }\end{array}$ & $\begin{array}{l}0.015 \\
0.269 \\
0.196\end{array}$ & $\begin{array}{l}0.747 \\
0.462 \\
0.148\end{array}$ & $\begin{array}{l}0.158 \\
0.391 \\
0.031\end{array}$ \\
\hline Inadequate monitoring and evaluation of the project & 0.223 & 0.676 & 0.197 \\
\hline $\begin{array}{l}\text { Inadequate funds by the farmers to buy farming inputs } \\
\text { Untimely supply of inputs by input agencies to the farmers }\end{array}$ & $\begin{array}{l}0.556 \\
0.569\end{array}$ & $\begin{array}{l}0.088 \\
0.109\end{array}$ & $\begin{array}{r}-0.311 \\
0.020\end{array}$ \\
\hline $\begin{array}{l}\text { Emergence of new species of weeds on new varieties of } \\
\text { soybean } \\
\text { Insecurity situation in rural areas (herdsmen attacks) } \\
\text { Top down approach in project design and implementation } \\
\text { Non- interaction between and among stake holders }\end{array}$ & $\begin{array}{l}0.200 \\
0.280 \\
0.297 \\
0.442\end{array}$ & $\begin{array}{l}0.387 \\
0.417 \\
0.509 \\
0.229\end{array}$ & $\begin{array}{l}0.134 \\
0.346 \\
0.391 \\
\mathbf{0 . 5 1 3}\end{array}$ \\
\hline $\begin{array}{l}\text { Inadequate fertile soil for soybean production } \\
\text { Embezzlement and corruption of MARKETS II officials } \\
\text { Culture /traditional farming practices of farmers } \\
\text { Inadequate extension agent's contact with farmers } \\
\text { Lack of technical knowhow } \\
\text { Lack of continuity of agricultural policies and projects }\end{array}$ & $\begin{array}{l}0.216 \\
0.005 \\
0.112 \\
0.020 \\
0.495 \\
0.195\end{array}$ & $\begin{array}{l}0.381 \\
\mathbf{0 . 4 3 5} \\
0.353 \\
0.034 \\
-0324 \\
\mathbf{0 . 4 4 5}\end{array}$ & $\begin{array}{r}-0.029 \\
0.028 \\
\mathbf{0 . 4 9 4} \\
\mathbf{0 . 6 0 3} \\
0.228 \\
0.337\end{array}$ \\
\hline $\begin{array}{l}\text { Disease and pest infestation on cultivated soybean } \\
\text { Poor educational status of farmers affect their acceptance of }\end{array}$ & 0.320 & -0.042 & -0.123 \\
\hline Innovations brought by the project & 0.014 & 0.005 & -0.222 \\
\hline Lack of modern storage and processing facilities & 0.397 & 0.057 & -0.127 \\
\hline $\begin{array}{l}\text { Drought factors such as shortage of rain fall affect the } \\
\text { project }\end{array}$ & 0.059 & 0.118 & 0.033 \\
\hline Communal land disputes among farming communities & 0.172 & 0.391 & -0.029 \\
\hline Inadequacy of modern storage and processing facilities & 0.397 & 0.057 & -0.127 \\
\hline Poor land tenure system and land unavailability & 0.071 & 0.346 & 0.157 \\
\hline Poor income realize from the new varieties of soybean & 0.115 & 0.146 & 0.346 \\
\hline Short life cycle of the new varieties of soybean & $0.318^{-}$ & 0.229 & 0.207 \\
\hline
\end{tabular}

Extraction method: Principal component analysis and Rotation method: Varimax with Kaiser normalization. Factor $1=$ Economic constraints, Factor $2=$ Institutional constraints and Factor 3 $=$ Linkage constraints 
Creative commons User License: CC BY-NC-ND

Abstracted by: EBSCOhost, Electronic Journals Service (EJS),

Google Scholar, Journal Seek, Scientific Commons,

Food and Agricultural Organization (FAO), CABI and Scopus
Journal of Agricultural Extension

Vol. 22 (3) October, 2018

ISSN(e): 24086851; ISSN(Print); 1119944X

http://journal.aesonnigeria.org

http://www.aiol.info/index.phpliae

Email: editorinchief@aesonnigeria.org

\section{Conclusion and Recommendations}

Economic, institution and linkage problems constrained the success of the project. States and federal Governments should provide logistic support such as provision of inputs subsidy to project participants and strengthen extension organization. The government and USAID MARKETS II should also provide soft loans to farmers participating in the project through cooperatives to purchase all the farming inputs they need, carry out necessary farming operations and adopt all the useful technologies to enhance productivity and ensure success of the project.

\section{References}

Adelodun, K. (2011). Soybeans biochemistry, chemistry and physiology retrieved from:http://www.intechopen.com/books/soybean-biochemistry-chemistry-andphysiology/soybean-africa-s-potential-cinderella-food-crop.

Agada, M. (2015). Constraints to increase soybean production in Benue State, Nigeria. Asian Journal of Agricultural Extension, Economics \& Sociology, 4(4): 277-284.

Ajayi, A. R. (2002). Changes in behaviour and social status as perceived by participating farmers in Agricultural Development Projects in Ondo and Enugu States, Nigeria. Agro-Science Journal of Tropical Agriculture, food, Environment and Extension, 3(1): 47-54.

Akinnagbe, O. M and Olaolu, M. O. (2016). Policy issues for improving monitoring and evaluation of agricultural extension programmes in Nigeria, Journal of African Evaluation Association Vol 14. N01 3(2).

Aphunu, A. and Nwabueze, G. (2012). Fish farmer's perception of climate change impact on fish production in Delta State, Journal of Agricultural Extension 2 (16):48.

Oriole, E. C. (2009).A framework for food security and poverty reduction in Nigeria, European Journal of Social Sciences, Vol. 8(1), pp. 37-43.

Biam, C. K. and Aja, O. (2012). Accelerating grain legumes production in Nigeria: prospects and challenges. Journal of Agricultural Science and Technology Volume 2, pp 627-641

Damola, A. A. (2010). Sector strategies and policies related to rice development in Nigeria. Mapping of poverty reduction strategies papers (PRSP) p 1-66, retrieved at www.riceforafrica.org.

Daudu, S.1. And Madukwe, M. C. (2013). Innovations in the soybean innovation system in Benue State, Nigeria. African Journal of Agricultural Research, 8 (28): 3702-3709. 
Creative commons User License: CC BY-NC-ND

Abstracted by: EBSCOhost, Electronic Journals Service (EJS),

Google Scholar, Journal Seek, Scientific Commons,

Food and Agricultural Organization (FAO), CABI and Scopus
Journal of Agricultural Extension

Vol. 22 (3) October, 2018

ISSN(e): 24086851; ISSN(Print); 1119944X

http://journal.aesonnigeria.org

http://www.ajol.info/index.php/iae

Email: editorinchief@aesonnigeria.org

Dimelu, M. U., Salifu, M U. and Igbokwe, E.M. (2016). Resource use conflict in agrarian communities, management and challenges: A case of farmer herdsmen conflict in Kogi State. Journal of Rural Studies 46 (148-154).

Ecocrop (2012).Agricultural and forest meteorology, retrieved from www.sciencedirect.com/science/journal/01681923/170.

Heuze, V. and Tran, G. (2015). Soybean (general), feedipedia; a programme by INRA, CIRAD, AFZ and FAO, retrieved from: http://www.feedipedia.org/node/753.

Mignouna, B., Manyong, M., Rusike, J., Mutabazi, S. and Senkondo, M. (2011). Determinants of adopting imazapyr-resistant maize technology and its impact on household income in western Kenya: Agbioforum, 14(3): 158-163.

Mustapha, S. B., Makinta, A. A., Zongoma, B. A. and Iwan, A. S. (2012). Socioeconomic factors affecting adoption of soya bean production technologies in Takum Local Government Area of Taraba State, Nigeria, Asian Journal Agriculture and Rural Development, 2 (2): 276-281.

Okoli, M. A. Agbasi, E. O. Anigbogu, T. U. (2015). Socioeconomic factors influencing agricultural production among cooperative farmers in Anambra State Nigeria,International Journal of Academic Research in Economics and Management Sciences,4 (5): 2226-3624.

Tiwari, N. (2010). Economic and technological constraints facing farm women, International Journal of Rural Studies, 17(1): 1-5.

Udemeze, J. (2013). Adoption of FARO-44 Rice production Technologies by farmers in Anambra State. M.Sc. Department of Agricultural Extension University of Nigeria, Nsukka.

USAID/MARKETS II (2013). Approved package of practices for soybean production (POP); Trainer's guide to out grower farmers for building capacity of soy farmers in Nigeria. Abuja, Pp 1-33. 